\title{
DINAMIKA LSM DALAM LEGISLASI KEBIJAKAN RESPONSIF GENDER: STUDI KASUS LSM DAMAR DI KOTA BANDAR LAMPUNG
}

\author{
Syamsul Ma'arif ${ }^{1}$
}

\begin{abstract}
This study was aimed to explain the social role that had been carried out, capacity building that had been done, and the capacity of the DAMAR NGO in fighting for the issuance of gender responsive public policies especially related to the fulfillment of women's basic rights. The results showed that the NGO DAMAR was successful in actualizing the social role of NGOs which included: supervision of the Government, policy advocacy and empowerment, and civic education even on a limited scale. Capacity building had been carried out by NGO DAMAR at various levels, both at the system level, institutional level, and individual level, so that making DAMAR NGOs have independence and self-sufficiency. But he had not been able to realize self-sufficiency through the establishment of productive business units. For this reason, NGO DAMAR was necessary to develop independent funding sources by transferring funding sources from abroad to local funding sources through the establishment of productive business units.
\end{abstract}

Keyword: NGO DAMAR, Public Policies, and Woman's Basic Rights

\begin{abstract}
ABSTRAK
Penelitian ini dimaksudkan untuk menjelaskan peran sosial yang telah dijalankan, pengembangan kapasitas, maupun kapasitas yang dimiliki LSM DAMAR dalam memperjuangkan keluarnya kebijakan publik yang responsif gender khususnya terkait dengan pemenuhan hak dasar kaum perempuan. Hasil penelitian menunjukkan bahwa LSM DAMAR berhasil melakukan aktualisasi peran sosial LSM yang mencakup: pengawasan terhadap Pemerintah, advokasi kebijakan dan pemberdayaan, dan pendidikan kewargaan meski dalam skala yang terbatas. Pengembangan kapasitas telah dilakukan LSM DAMAR pada berbagai tingkatan, baik tingkat sistem, tingkat institusi, maupun tingkat individu sehingga membuat LSM DAMAR memiliki kemandirian dan keswadayaan. Namun ia belum mampu merealisasikan keswasembadaan melalui pembentukan unit usaha produktif. Untuk itu LSM DAMAR perlu mengembangkan sumber pendanaan mandiri dengan cara mengalihkan sumber pendanaan dari luar negeri ke sumber pendanaan lokal melalui pembentukan unit-unit usaha produktif.
\end{abstract}

Kata Kunci: LSM DAMAR, Kebijakan Publik, dan Hak Dasar Kaum Perempuan

1. Dosen, Program Studi Ilmu Administrasi Negara Fakultas Ilmu Sosial dan Ilmu Politik Universitas Lampung, email: symaarif@unila.ac.id; symaarif@gmail.com 


\section{PENDAHULUAN}

Pemenuhan Hak dasar kaum perempuan merupakan kebutuhan warga negara yang wajib disediakan oleh negara sesuai dengan amanat konstitusi. Dengan berbagai perangkat yang dimilikinya, negara sesungguhnya telah berusaha melakukan langkah yang terbaik untuk memenuhinya. Namun negara dalam hal ini pemerintah tetaplah memiliki keterbatasan ketika harus melaksanakan tugasnya mengingat demikian luas dan panjangnya jangkauan pelayanan yang harus ditanganinya. Demikian pula di pihak masyarakat, seringkali keinginan masyarakat terutama masyarakat lapisan menengah ke bawah tak dapat sepenuhnya terakomodasi dalam pembuatan kebijakan pemerintah. Situasi semacam ini di Kota Bandar Lampung mendorong lahirnya LSM DAMAR selaku organisasi masyarakat sipil yang tampil ke depan untuk memainkan peran strategis, yaitu mengisi kekosongan ruang yang tidak terjangkau oleh pemerintah sekaligus memperkuat posisi masyarakat sipil khususnya kaum perempuan agar dapat dapat mempengaruhi pembuatan kebijakan pemerintah.

LSM berbeda dengan Ormas meskipun keduanya merupakan bagian dari organisasi masyarakat sipil.
Ketentuan mengenai Lembaga Swadaya Masyarakat diatur dalam Instruksi Menteri Dalam Negeri Nomor 8 Tahun 1990 Tentang Pembinaan Lembaga Swadaya Masyarakat. Pengertian Lembaga Swadaya Masyarakat seperti tercantum dalam ketentuan tersebut adalah organisasi/lembaga yang anggotanya masyarakat warga negara Republik Indonesia yang secara sukarela atau kehendak sendiri berniat serta bergerak di bidang kegiatan tertentu yang ditetapkan oleh organisasi/lembaga sebagai wujud partisipasi masyarakat dalam upaya meningkatkan taraf hidup dan kesejahteraan masyarakat yang menitik beratkan pada pengabdian secara swadaya. Sementara itu Organisasi Kemasyarakatan (Ormas) tunduk pada ketentuan Undang-Undang Nomor 17 Tahun 2013 Tentang Ormas di mana Ormas adalah semua organisasi yang didirikan dan dibentuk oleh masyarakat secara sukarela berdasarkan kesamaan aspirasi, kehendak, kebutuhan, kepentingan, kegiatan, dan tujuan untuk berpartisipasi dalam pembangunan demi tercapainya tujuan Negara Kesatuan Republik Indonesia yang berdasarkan Pancasila. 
Secara formal, LSM mencerminkan pelembagaan partisipasi warga untuk turut mempengaruhi pembuatan kebijakan pemerintah. Eksistensi LSM ditandai dengan adanya intensitas interaksi yang tinggi secara langsung dengan warga masyarakat. Aktivitas tersebut memungkinkan LSM memainkan peran fungsional yaitu peran mediasi dalam rangka menjembatani jarak perbedaan antara warga masyarakat dengan pemerintah. Untuk itu, LSM diharapkan dapat berperan mendorong terjadinya perubahan sosial melalui penguatan kapasitas masyarakat sipil. Perubahan sebagaimana yang dimaksudkan tentu saja menempatkan warga masyarakat sebagai pelaku utama perubahan. Pola semacam ini dikenal sebagai model legislasi yang berbasiskan komunitas.

Gejala yang demikian juga dapat dijumpai dalam konteks dinamika sosial politik lokal di Kota Bandar Lampung. Dalam penyelenggaraan urusan publik di Kota Bandar Lampung telah muncul gejala perubahan yang ditandai: (1) Adanya kesadaran baru tentang kebijakan publik, di mana kebijakan tersebut pada prosesnya harus melibatkan partisipasi langsung masyarakat; (2) Adanya keinginan bersama menuju terciptanya kebijakan yang responsif, yakni kebijakan yang memiliki substansi yang diangkat dari realitas obyektif masyarakat. Kemunculan Lembaga Swadaya Masyarakat seperti LSM DAMAR mewakili jawaban atas kesadaran kolektif kaum perempuan yang menuntut agar kebijakan daerah sepenuhnya berpihak pada kepentingan warga masyarakat. Terkait dengan aktivitas LSM DAMAR, studi ini dimaksudkan untuk menjawab tiga pertanyaan: (1) Bagaimanakah penerapan peran sosial LSM DAMAR dalam pemenuhan hak dasar kaum perempuan; (2) Bagaimanakah kapasitas LSM Damar dalam melaksanakan peran sosialnya bagi pemenuhan hak dasar kaum perempuan; dan (3) Bagaimanakah pengembangan kapasitas yang dilakukan LSM DAMAR dalam rangka meningkatkan kemampuannya untuk memenuhi hak dasar kaum perempuan.

Menurut Eldridge (1989), LSM selaku organisasi masyarakat sipil memiliki tiga peran pokok yaitu memberdayakan masyarakat dengan membentuk organisasinya sendiri sesuai dengan kebutuhannya, mewujudkan nilainilai dan melakukan pendekatan partisipatoris dalam pengembangan masyarakat, serta menjadi wakil 
masyarakat dalam memperjuangkan kepentingan-kepentingannya. Kapasitas LSM selaku organisasi masyarakat sipil dalam menjalankan peran sosialnya, menurut Hadi (2010:119), dapat diukur dengan menggunakan tiga parameter, yaitu otonomi, keswadayaan, dan keswasembadaan. Otonomi yang didefinisikan sebagai kemampuan mengambil sikap tanpa campur tangan pihak eksternal dapat dilihat dari tolok ukur seperti: kemampuan mengorganisir sendiri, kemampuan mengelola sumber daya manusia sendiri (rekrutmen, seleksi, partisipasi), dan kemampuan membangun jaringan dengan sesame organisasi masyarakat sipil. Keswadayaan yang didefinisikan sebagai kemampuan memenuhi kebutuhannya sendiri dapat dilihat dari tolok ukur seperti: kemampuan menggalang dana dari anggota, kemampuan menggalang dana kemitraan dengan pemerintah, kemampuan menggalang dana kemitraan dengan organisasi lain, dan kemampuan menggalang dana kemitraan dengan lembaga internasional. Keswasembadaan yang didefinisikan sebagai kemampuan mengelola usaha untuk kepentingan menghidupkan organisasi sendiri dapat dilihat dari tolok ukur ada tidaknya kegiatan pengelolaan usaha produktif yang dimaksudkan sebagai sumber pemenuhan kebutuhan organisasi.

Pengembangan kapasitas adalah suatu proses yang dapat meningkatkan kemampuan seseorang, suatu organisasi atau suatu sistem untuk mencapai tujuantujuan yang dicita-citakan (Brown, 2001:25). Guna mewujudkan tujuan tersebut, pengembangan kapasitas menurut Soeprapto (2010) perlu dilakukan secara efektif dan berkesinambungan melalui berbagai tingkatan tertentu yang meliputi: (1) tingkatan sistem, seperti kerangka kerja yang berhubungan dengan pengaturan, kebijakan-kebijakan dan kondisi dasar yang mendukung pencapaian obyektivitas kebijakan tertentu; (2) tingkatan institusional atau keseluruhan satuan, contoh struktur organisasi-organisasi, proses pengambilan keputusan di dalam organisasi-organisasi, prosedur dan mekanisme-mekanisme pekerjaan, pengaturan sarana dan prasarana, hubungan-hubungan dan jaringanjaringan organisasi; (3) tingkatan individual, contohnya ketrampilanketrampilan individu dan persyaratanpersyaratan, pengetahuan, tingkah laku, pengelompokan pekerjaan dan motivasi-motivasi dari pekerjaan orangorang di dalam organisasi-organisasi. 


\section{METODE}

Penelitian ini berlangsung di Kota Bandar Lampung karena didasari pertimbangan: pertama, posisi strategis Kota Bandar Lampung sebagai ibukota Provinsi Lampung menempatkan kota ini sebagai barometer dinamika perkembangan kehidupan sosial politik lokal bagi daerah-daerah lainnya di Provinsi Lampung; kedua, Kota Bandar Lampung merupakan daerah tempat kedudukan dari LSM tersebut. Kegiatan penelitian dilakukan dengan menggunakan metode penelitian kualitatif dan tipe penelitian deskriptif. Data dan informasi yang dikumpulkan mencakup data primer yang dikumpulkan di lapangan maupun data sekunder yang berasal dari sumber-sumber tertulis. Selanjutnya data dianalisis dengan menggunakan metode analisis data kualitatif. yang dilakukan melalui langkah-langkah reduksi data, penyajian data, yang diakhiri dengan verifikasi dan penarikan kesimpulan.

\section{HASIL DAN PEMBAHASAN}

\section{Profil LSM DAMAR}

LSM DAMAR pada awalnya didirikan pada tanggal 5 Oktober 1995 dengan nama ELSAPA. Namun sejak 10 Februari 2000, atas kesepakatan para pengurus nama ELSAPA dirubah menjadi DAMAR. DAMAR memiliki arti lampu penerang sehingga secara filosofis DAMAR diharapkan mampu menerangi masyarakat khusus perempuan korban tindak kekerasan. Selain itu DAMAR juga diambil dari nama pohon yang menjadi icon Provinsi Lampung dengan harapan agar DAMAR dalam kiprahnya bisa menjadi icon bagi warga Provinsi Lampung.

LSM DAMAR merupakan organisasi berbentuk perkumpulan yang berbasiskan keanggotaan. Di dalamnya terdapat tiga lembaga eksekutif, yaitu Lembaga Advokasi Perempuan, Lembaga Advokasi Anak, dan Institut Pengembangan Organisasi \& Riset. Isu yang menjadi perhatian utama lembaga ini adalah menyangkut masalah gender, anak, dan hukum. Sementara itu isu lainnya yang juga menjadi perhatian adalah masalah hak asasi manusia dan demokrasi. Penanganan atas isu-isu tersebut diwujudkan terutama dalam bentuk kegiatan advokasi. Kegiata itu didukung dengan kegiatan lainnya seperti studi, penelitian atau survai, pendidikan dan pelatihan, pengembangan dan pendampingan masyarakat, penerbitan/publikasi, dan seminar, diskusi atau lokakarya. 
Pembentukan LSM DAMAR berangkat dari keprihatinan atas terjadinya peningkatan tindak kekerasan, ketidakadilan, dan tidak demokratisnya perlakuan terhadap perempuan dan anakanak. Kondisi tersebut tak lepas dari pengaruh kuatnya nilai-nilai patriarkhi di tengah masyarakat yang menimbulkan budaya dan kebijakan yang tidak adil bagi kaum perempuan. Oleh karena itulah LSM DAMAR berdiri dengan tujuan utama untuk memberikan bantuan hukum secara cuma-cuma kepada kaum perempuan dan anak-anak yang tidak berdaya tanpa membedakan agama, keturunan, suku, keyakinan politik, maupun sosial budaya, dan menyebarluaskan hak dan kewajiban nilai-nilai hukum dan hak asasi manusia pada kaum perempuan dan anak sebagai subjek hukum.

\section{Peran sosial LSM DAMAR}

Aktualisasi peran sosial LSM DAMAR diwujudkan melalui serangkaian aktivitas seperti: pengawasan terhadap Pemerintah, advokasi kebijakan dan pemberdayaan, serta pendidikan kewargaan. Ketiga macam peran sosial tersebut saling mendukung satu sama lain. Pengawasan terhadap Pemerintah mendorong keluarnya berbagai produk kebijakan yang lebih pro-rakyat. Advokasi dan pemberdayaan masyarakat mendorong timbulnya pola hubungan kemitraan antara LSM dan Pemerintah Daerah. Sedangkan keberhasilan penerapan kedua peran sosial tersebut tak lepas dari dukungan terbatas masyarakat sebagai hasil dari aktivitas pendidikan kewargaan.

Di Kota Bandar Lampung, pelaksanaan peran LSM untuk melakukan pengawasan atas pemerintah dilakukan dengan menjalin koalisi sesama LSM terutama yang memiliki kesamaan platform. Selain itu juga dikembangkan semangat bahwa LSM adalah mitra sejajar pemerintah. Secara langsung, LSM-LSM ingin menunjukkan bahwa sekalipun aspirasi yang mereka sampaikan merupakan perwujudan keingingan rakyat, namun tidak berarti antara LSM dengan Pemerintah Daerah berada dalam posisi yang saling berhadapan. Gagasan untuk memainkan peran sosial sebagai kekuatan pengawasan antara lain ditunjukkan oleh LSM DAMAR melalui kerjasama reguler dengan LSM PUSSBIK (Pusat Studi Kebijakan Publik) dalam mengadakan diskusi, seminar dan pertemuanpertemuan antar kelompok masyarakat sipil terkait dengan politik anggaran 
kesehatan dan kebijakan penanggulangan gizi buruk dan busung lapar.

Sebagai representasi kekuatan masyarakat sipil, LSM DAMAR secara normatif melakukan upaya-upaya mengorganisir dan menyuarakan kepentingan masyarakat sipil khususnya kaum perempuan agar kepentingannya dapat diakomodasi oleh pemerintah. Upaya yang popular disebut Advokasi ini dilakukan dengan memandang bahwa pemenuhan hak dasar kaum perempuan merupakan kerja kolektif yang perlu didukung dengan berbagai strategi karena implementasi kebijakannya di lapangan hingga kini dinilai belum berjalan maksimal. Strategi pendekatan LSM DAMAR untuk mewujudkan perubahan kebijakan menuju perilaku yang adil gender ditempuh dengan cara berjaringan, metoda pendidikan kritis, serta penguatan perspektif gender dan feminis dengan tujuan membangun perspektif stakeholder mengenai hak dasar kaum perempuan agar peka dan responsif gender. Untuk itu LSM DAMAR membagi menjadi stakeholder menjadi tiga bagian utama, yaitu pemerintah sebagai pemberi layanan kesehatan, legislatif sebagai pembuat kebijakan yang lebih peka gender, serta tokoh agama dan adat sebagai pihak terdekat yang memberikan informasi dan rujukan langsung di masyarakat.

LSM DAMAR khususnya Lembaga Advokasi Perempuan sejak tahun 2000 telah melakukan advokasi anti kekerasan dan berhasil mendorong perubahan kebijakan seperti: terbentuknya memorandum of understanding di antara berbagai pemangku kepentingan untuk memberikan pelayanan kepada perempuan korban tindak kekerasan, baik di tingkat propinsi maupun kabupaten/kota; (2) terbentuknya Unit Pelayanan Terpadu Perempuan Korban Tindak kekerasan di Rumah Sakit Abdoel Moeloek yang memberikan pelayanan secara khusus dan gratis; (3) Pemerintah Provinsi Lampung telah mengalokasikan dana yang digunakan untuk pelayanan dan pendampingan bagi perempuan korban tindak kekerasan; (4) keluarnya Perda Nomor 4 Tahun 2006 Tentang Pencegahan Perdagangan Perempuan dan Anak; (5) keluarnya Perda Nomor 6 Tahun 2006 Tentang Pelayanan Terhadap perempuan dan Anak Korban Kekerasan.

Dengan adanya berbagai kebijakan tersebut, LSM DAMAR memandang pelayanan yang diberikan kepada perempuan korban tindak kekerasan dirasakan sudah cukup 
mengakomodasi kepentingan kaum perempuan. Oleh karena itu, pada tahun 2009 LSM DAMAR menjadikan "Pemenuhan Hak Dasar Kaum Perempuan" yang meliputi: pemenuhan Hak Kesehatan Ibu dan Anak, Pendidikan Dasar Bagi Semua Secara Gratis dan Berkualitas, Hak Politik Kaum Perempuan, Anti Kekerasan Terhadap Perempuan, dan Anti Pemiskinan sebagai isu utama. Isu tersebut dituangkan ke dalam visi, misi, dan peran strategis, dengan didasari nilai-nilai tertentu. Visi LSM DAMAR adalah terwujudnya pemenuhan hak dasar perempuan agar tercipta masyarakat yang demokratis menuju keadilan untuk semua. Misi LSM DAMAR adalah: (1) meningkatnya pemahaman dan kepedulian pemerintah daerah dan masyarakat tentang hak dasar kaum perempuan; (2) menguatnya basis dalam melakukan advokasi kaum perempuan sebagai bagian dari gerakan sosial; (3) menguatnya kapasitas organisasi maupun kelembagaan LSM DAMAR dan perkumpulan DAMAR sebagai organisasi yang independen dalam mewujudkan transparansi, akuntabilitas, dan kinerjanya. Visi dan misi tersebut diwujudkan melalui pelaksanaan peran strategis yaitu dengan melakukan advokasi penguatan hak dasar kaum perempuan maupun melakukan penguatan kelompok dan pendidikan kritis bagi kaum perempuan. Kesemuanya dilakukan dengan didasari nilai-nilai anti diskriminasi, non partisan, independen, pluralism, keadilan, dan kesetaraan.

Berkaitan dengan pendidikan kewargaan, LSM Damar secara tegas menyatakan bahwa peran strategis yang dijalankannya antara lain adalah melakukan penguatan masyarakat sipil khususnya perempuan marjinal melalui pendidikan kritis; pengorganisasian, penguatan, dan konsolidasi organisasi perempuan lintas wilayah se-Lampung dengan harapan agar organisasiorganisasi perempuan se-Lampung bisa melakukan advokasi atas hak dasarnya. Peran ini diwujudkan melalui Program Kajian dan Pendidikan Publik yang dilakukan untuk memetakan persoalan hak dasar perempuan (hak kesehatan, hak pendidikan, dan hak politik) di lima Kabupaten/Kota (Bandar Lampung, Tanggamus, Lampung Tengah, Lampung Timur, dan Lampung Selatan). Pemetaan juga didukung data base sebagai fakta atau gambaran persoalan hak dasar yang terjadi di masyarakat.

Selain itu, pendidikan kewargaan juga diwujudkan antara lain melalui 
penyelenggaraan berbagai dialog publik dengan tema "Segerakan Pemenuhan Hak Kesehatan Seksual dan Reproduksi (HKSR) Perempuan”, di Gedung Korpri, Lampung Utara, Senin, 27 April 2015. Kegiatan yang diselenggarakan bekerja sama dengan Kesatuan Perempuan Lampung Utara (Kepal Utara) ini dlakukan untuk menyikapi kenyataan bahwa kasus kekerasan atas kaum perempuan yang terjadi di Lampung Utara menempati urutan ke-3 terbanyak di Lampung. Kasus-kasus tersebut memiliki ciri khas yaitu tidak dibawa ke hukum formal, tetapi disembunyikan dan dibuat seolah-olah berlindung di balik hukum adat, sehingga apabila terjadi kasus kekerasan, penyelesaiannya kerap dilakukan bawah tangan. Mengingat informasi tentang kesehatan seksual dan reproduksi belum banyak diketahui oleh masyarakat, maka salah satu poin penting dari dialog ini adalah adanya kesepahaman bahwa kegiatan sosialisasi tentang Hak Kesehatan Seksual dan Reproduksi ini penting dilakukan hingga di tingkat desa.

\section{Kapasitas LSM DAMAR}

Kapasitas LSM DAMAR dapat dilihat dari tolok ukur yang meliputi kemandirian, keswadayaan, dan keswasembadaan. Terkait dengan kemandirian LSM, LSM Damar berhasil mewujudkan kemandirian dalam arti bebas menentukan sikap tanpa terhambat intervensi pihak eksternal khususnya Pemerintah baik Pusat maupun Daerah. Hal ini dipengaruhi oleh sturktur pendanaan organisasi yang lebih banyak berasal dari donor internasional, seperti dari Ford Foundation, Asia Foundation, Tifa Foundation, Hivos, dan Oxfam. Kemandirian Damar ditunjukkan sejak tahun 2000 hingga 2008 khususnya melalui Lembaga Advokasi Perempuan ketika melakukan berbagai aksi advokasi anti kekerasan. LSM Damar turun ke masyarakat menyerap berbagai aspirasi hak dasar kaum perempuan yaitu hak pendidikan, hak politik, ekonomi, kesehatan, dan hukum. Manifestasinya diwujudkan dengan melakukan pendidikan kritis melalui empat tahap yaitu pendidikan adil gender, pendidikan feminis dan analisis sosial, pendidikan kepemimpinan, dan pendidikan tata kelola pembangunan. LSM Damar menginventarisasi permasalahan masyarakat untuk kemudian menginformasikannya agar dapat dirumuskan sebuah solusi melalui media massa, artikel-artikel pendidikan politik, penyuluhan-penyuluhan, pelatihan- 
pelatihan, dan berbagai lomba berkaitan dengan gender. Pada tingkat elit, LSM Damar melakukan lobi-lobi untuk turut merumuskan solusi atas isu-isu yang ada di masyarakat. Beberapa usulan LSM Damar di antaranya: (1) perlu ada suatu Perda mengenai pencegahan trafficking; (2) perlu ada Perda mengenai perlindungan perempuan dan anak; (3) perlu ada revisi atas Perda Nomor 4 Tahun 2011 tentang Pengarusutamaan Gender dalam Pembangunan di Daerah.

Upaya ini menghasilkan beberapa kebijakan antara lain: (1) terbentuknya memorandum of understanding di antara berbagai pemangku kepentingan untuk memberikan pelayanan kepada perempuan korban tindak kekerasan, baik di tingkat propinsi maupun kabupaten/kota; (2) terbentuknya Unit Pelayanan Terpadu Perempuan Korban Tindak kekerasan di Rumah Sakit Abdoel Moeloek yang memberikan pelayanan secara khusus dan gratis; (3) Pemerintah Provinsi Lampung telah mengalokasikan dana yang digunakan untuk pelayanan dan pendampingan bagi perempuan korban tindak kekerasan; (4) keluarnya Perda Nomor 4 Tahun 2006 Tentang Pencegahan Perdagangan Perempuan dan Anak; (5) keluarnya Perda Nomor 6 Tahun 2006 Tentang Pelayanan Terhadap perempuan dan Anak Korban Kekerasan; (6) keluarnya Perda Nomor 10 Tahun 2011 Tentang Pengarusutamaan Gender Dalam Pembangunan di Daerah.

$\begin{array}{crrr}\text { Salah } & \text { satu faktor } & \text { yang } \\ \text { mempengaruhi } & \text { kemandirian } & \text { LSM }\end{array}$
DAMAR adalah kemampuannya membangun jaringan kerjasama dengan sesama LSM. Kemampuan ini diwujudkan dalam bentuk pengembangan jaringan koalisi untuk membantuk kemandirian LSM. Kemampuan ini telah diperlihatkan oleh LSM DAMAR bersama dengan LSM PUSSBIK melalui kerjasama secara reguler dalam bentuk penyelenggaraan diskusi, seminar, dan pertemuan-pertemuan antar kelompok masyarakat sipil terkait dengan politik anggaran kesehatan maupun kebijakan penanggulangan gizi buruk dan busung lapar. LSM DAMAR juga telah membangun jaringan dengan organisasi serikat perempuan di 6 kabupaten/kota se-Provinsi Lampung, seperti Forum Advokasi Kemanusiaan Tanggamus, Serikat Perempuan Lampung Selatan, Serikat Perempuan Bandar Lampung, Perempuan Timur, Forum Advokasi Kemanusiaan Lampung Tengah, Kesatuan Perempuan Lampung Utara). Begitu pula di level Sumatera, LSM DAMAR ikut bergabung menjadi 
anggota dari Konsorsium Perempuan Sumatera Mampu (Permampu), sebuah konsorsium yang didirikan atas dasar perjuangan untuk menguatkan kepemimpinan perempuan akar rumput dalam pemenuhan hak dasar kaum perempuan di Sumatera. Penguatan kepemimpinan perempuan itu dilakukan melalui perlindungan dan pemenuhan hak-hak dasar kaum perempuan, khususnya perempuan di pedesaan dan perempuan miskin di kota. Melalui forum tersebut, LSM DAMAR terus menerus berupaya meningkatkan pengetahuan para relawan mengenai cakupan hak dasar kaum perempuan, kebijakan mengenai kesehatan dan hak dasar kaum perempuan, serta berbagai strategi advokasi kebijakan dan pendidikan kritis stakeholder.

Faktor lainnya yang mempengaruhi kemandirian LSM DAMAR adalah manajemen organisasi yang terkait dengan rekrutmen pengurus dan staff. Faktor ini amat penting mengingat aktivitas LSM DAMAR yang berfokus pada pendidikan adil gender, pendidikan feminis dan analisis sosial, pendidikan kepemimpinan, dan pendidikan tata kelola pembangunan memang mensyaratkan dukungan kualitas sumber daya manusia yang tinggi dengan pengelolaan professional. Dukungan sumber daya manusia berupa pengurus dan staff lulusan pendidikan tinggi diperoleh LSM DAMAR melalui rekrutmen para aktivis yang berlatarbelakang akademisi maupun bekerjasama dengan Pusat Studi Wanita di masing-masing perguruan tinggi. Sementara itu, untuk meningkatkan kapasitas pengelolaan organisasi, LSM DAMAR secara rutin melaksanakan pelatihan para pengurus dan aktivis.

Berkaitan dengan keswadayaan, keberlanjutan aktivitas sebuah LSM mensyaratkan dukungan dari masyarakat. Di Kota Bandar Lampung, sambutan masyarakat atas aktivitas LSM DAMAR pada umumnya positif karena masyarakat menilai bahwa aktivitas LSM DAMAR memiliki keberpihakan kepada kepentingan masyarakat luas khususnya dalam hal memperjuangkan pemenuhan hak-hak kaum perempuan. Begitu pula, pihak Pemerintah Kota Bandar Lampung merespon positif aktivitas LSM DAMAR karena para aktivisnya mampu mempertahankan idealismenya di tengah citra buram yang diperlihatkan oleh banyak LSM di tanah air. Meski demikian, upaya untuk membangun voluntarisme masyarakat tidak menjadi prioritas mengingat LSM DAMAR telah 
memiliki sumber pendanaan yang memadai untuk menggaji para pengurus eksekutif maupun para staf.

Sisi lain dari upaya membangun keswadayaan adalah dengan menggalang fund raising. Namun demikian, sumbersumber utama fund raising tetaplah mengandalkan dana yang berasal dari lembaga donor di luar negeri seperti: Ford Foundation, Asia Foundation, TIFA Foundation, Hivos, Oxfam, dll. Selanjutnya berkaitan dengan keswasembadaan, idealnya sebuah LSM memiliki unit usaha produktif yang dapat dijadikan sebagai sumber pendanaan baik pendanaan mandiri maupun pendanaan dari masyarakat secara partisipatif bagi organisasi agar tidak tergantung kepada donor. Bagi LSM DAMAR, hal itu sulit dilaksanakan karena: pertama, sejak awal tidak memiliki basis donatur lokal sehingga agak beresiko kalau hendak mengalihkan sumber pendanaan dari luar negeri ke donatur lokal; dan kedua, LSM bukanlah lembaga bisnis dan para pengurus maupun staf rata-rata adalah kalangan aktivis dan bukan wirausahawan sehingga agak sulit kalau hendak diarahkan ke kegiatan bisnis. Hal ini membuat keberlangsungan kegiatan LSM DAMAR masih bergantung pada sumber pendanaan dari luar negeri.
Pengembangan Kapasitas LSM DAMAR

Pengembangan kapasitas LSM dipandang penting karena langkah tersebut merupakan sebuah ikhtiar untuk meningkatkan kemampuan LSM dalam menjalankan peran sosialnya. Pengembangan kapasitas dilakukan pada tiga tingkat yaitu tingkat sistem, tingkat institusi, dan tingkat individu. pengembangan kapasitas di tingkat sistem diwujudkan melalui kegiatan pengayaan strategi demi penguatan gerakan. pengembangan kapasitas di tingkat institusi diwujudkan melalui perbaikan tata kelola organisasi demi penguatan gerakan. pengembangan kapasitas di tingkat individu diwujudkan melalui kegiatan peningkatan kemampuan personil demi penguatan gerakan.

Pengembangan di tingkat sistem dilakukan LSM DAMAR antara lain dengan mengembangkan berbagai strategi yang pernah dilakukan di lapangan untuk memenuhi dan melindungi HKSR perempuan dan remaja, khususnya melalui pengorganiasian perempuan di akar rumput. Hal ini memerlukan adanya pemahaman yang sama di kalangan multi-stakeholder (masyarakat, lembaga 
adat, lembaga agama, dan pemerintah) terhadap isu yang akan diusung. Pengembangan diwujudkan Lembaga Advokasi Perempuan DAMAR melalui penyelenggaraan Workshop Penyusunan Alur dan Materi Training Tentang Gender dan Hak Kesehatan Seksual Reproduksi (HKSR) Untuk Stakeholder, selama 3 hari, 15-17 Agustus 2015, di Griya Inayah, Jalan Wolter Monginsidi Nomor 117 Pengajaran, Bandar Lampung.

Para peserta Workshop yang terdiri dari para personel LSM DAMAR, perwakilan Pengurus Serikat Perempuan 6 kabupaten/kota (Fakta Tanggamus, Serikat Perempuan Lampung Selatan, Serikat Perempuan Bandar Lampung, Serikat Perempuan Lampung Timur, Forum Advokasi Kemanusiaan Lampung Tengah, Kesatuan Perempuan Lampung Utara) ini melaksanakan kegiatan dengan menghadirkan narasumber Komisioner Komnas Perempuan Budi Wahyuni dan Komisioner Komnas HAM Siti Noor Laila. Selama tiga hari workshop para peserta menyusun modul dengan menggali dan memetakan kebutuhan terkait alur dan materi training gender dan HKSR untuk stakeholder. Melalui penyusunan modul yang sesuai dengan realitas obyektif di tengah masyarakat, diharapkan modul tersebut dapat digunakan sebagai acuan untuk membantu para aktivis Serikat Perempuan, minimal menjawab salah satu dari sekian banyak persoalan yang terjadi di masyarakat terkait Hak Kesehatan Seksual dan Reproduksi.

Pengembangan kapasitas di tingkat institusi dilakukan LSM DAMAR dengan mengembangkan tata kelola organisasi di antaranya adalah sistem perencanaan, monitoring, evaluasi, keuangan, personalia, dan pembinaan staf. Rapat Umum Anggota dilaksanakan setiap lima tahun sekali membahas Kebijakan-Kebijakan, Garis Besar Haluan Organisasi, dan Kepemimpinan. Rapat Tahunan Anggota dilaksanakan satu tahun sekali membahas kondisi laporan akhir tahun, perencanaan tahunan, dan melihat kondisi real di lapangan.

Sementara itu pengembangan kapasitas di tingkat individu dilakukan LSM DAMAR dengan menyelenggarakan in house training (IHT) pendidikan atau penyadaran gender dan HKSR yang diselenggarakan di Wisma Inayah Telukbetung selama tiga hari Minggu hingga Selasa 25-27 Januari 2015. IHT diikuti oleh seluruh personel DAMAR, ditambah perwakilan dua 
orang Pengurus Serikat Perempuan pada enam kabupaten dan kota masing-masing, yaitu: FAKTA Tanggamus, Serikat Perempuan Lampung Selatan, Serikat Perempuan Bandar Lampung, Perempuan Timur, dan Kesatuan Perempuan Lampung Utara. Pelatihan ini dimaksudkan untuk meningkatkan kapasitas personel DAMAR dan Pengurus Serikat Perempuan pada enam kabupaten dan kota (yaitu FAKTA Tanggamus, Sepalas, SPBL, Perempuan Timur, FAK Lampung Tengah, Kepal Utara) mengenai cakupan dari hak kesehatan seksual reproduksi (HKSR), serta aturan-aturan yang mendasarinya baik secara nasional maupun internasional.

Pelatihan yang menghadirkan narasumber Zumrotin dari Yayasan Kesehatan Perempuan dan Dwi Hafsah dari PKBI Lampung ini, menghadirkan pula narasumber dari unsur Pemerintah Provinsi Lampung yaitu Dinas Kesehatan dan Dinas Pendidikan untuk mengetahui kebijakan Pemerintah Provinsi Lampung dalam pemenuhan Hak Kesehatan Seksual dan Reproduksi dan implementasi Peraturan Pemerintah Nomor 61 Tahun 2014 tentang Kesehatan Reproduksi. Evaluasi atas kebijakan yang telah berjalan diharapkan dapat menjadi pijakan dalam memperkuat strategi advokasi HKSR serta metoda pendidikan kritis yang berhubungan dengan HKSR.

\section{SIMPULAN}

1. Upaya LSM DAMAR dalam pemenuhan hak dasar kaum perempuan kesemuanya berhasil diwujudkan ke dalam bentuk aktualisasi peran sosial LSM yang mencakup: pengawasan terhadap Pemerintah, advokasi kebijakan dan pemberdayaan, dan pendidikan kewargaan meski dalam skala yang terbatas.

2. Pengembangan kapasitas LSM DAMAR telah dilakukan pada berbagai tingkatan, baik tingkat sistem, tingkat institusi, maupun tingkat individu.

3. Kapasitas LSM DAMAR jika dilihat dari parameter kemandirian, keswadayaan, dan keswasembadaan menunjukkan hasil bahwa LSM DAMAR memiliki kemandirian, keswadayaan, namun belum mampu merealisasikan keswasembadaan melalui pembentukan unit usaha produktif.

4. Sumber pendanaan LSM DAMAR yang berasal dari luar negeri membuat LSM ini mampu bersikap independen 
dalam berinteraksi dengan pemerintah

di dalam negeri, namun rentan

mengalami intervensi dari lembaga

donor luar negeri.

5. Untuk itu LSM DAMAR perlu mengembangkan sumber pendanaan mandiri dengan cara mengalihkan sumber pendanaan dari luar negeri ke sumber pendanaan lokal melalui pembentukan unit-unit usaha produktif.

\section{DAFTAR PUSTAKA}

Brown, Lisanne; LaFond Anne; Macintyre, Kate. 2001. Measuring Capacity Building. Chapel Hill: Carolina Population Centre/University of Nort Carolina.

Eldridge, Philiph J. (1989). LSM dan Negara. PRISMA No 7. Jakarta: LP3ES

Hadi, Oto. H. 2010. "Peran Masyarakat Sipil Dalam Proses Demokratisasi", dalam: Makara Sosial Humaniora, Vol. 14, No. 2, Desember 2010. hlm. 117-129.

Instruksi Menteri Dalam Negeri Nomor 8 Tahun 1990 Tentang Pembinaan Lembaga Swadaya Masyarakat.

Soeprapto, Riyadi. 2010. The Capacity Building For Local Government Toward Good Governance. Word Bank.

Undang-Undang Nomor 17 Tahun 2013 Tentang Organisasi Kemasyarakatan. 